\title{
Land Consolidation in Rural China: Life Satisfaction among Resettlers and Its Determinants
}

\author{
Weiming Tong ${ }^{1,2} \mathbb{C}$, Kevin Lo ${ }^{3} \mathbb{D}$ and Pingyu Zhang ${ }^{4,5, *}$ \\ 1 College of Economics, Zhejiang University of Technology, Hangzhou 310023, China; \\ tongweiming@zjut.edu.cn \\ 2 Department of The Built Environment, Eindhoven University of Technology, \\ 5600 MB Eindhoven, The Netherlands \\ 3 Department of Geography, Hong Kong Baptist University, Hong Kong, China; lokevin@hkbu.edu.hk \\ 4 Northeast Institution of Geography and Agroecology, Chinese Academy of Sciences, \\ Changchun 130102, China \\ 5 College of Resources and Environment, University of Chinese Academy of Sciences, Beijing 100049, China \\ * Correspondence: zhangpy@iga.ac.cn
}

Received: 25 February 2020; Accepted: 9 April 2020; Published: 14 April 2020

\begin{abstract}
The Chinese government has pursued rural land consolidation under the Building New Rural Communities (BNRC) initiative. The consolidation projects aim to address the hollowing village problem, improve the living standards of rural dwellers, and promote urban-rural integration. Rural villages with small populations and poor infrastructure are merged into a centralized rural community, and their inhabitants are resettled. The newly vacated buildings are then converted to agriculture land, which allows cities to expand under the "no net loss" land-use policy. Despite the significance of the initiative, both in terms of the scale of operation and the impacts on the affected households, there are few empirical studies that scrutinize this form of rural restructuring. Drawing on data collected via surveys and interviews, this paper examines the processes of land consolidation and its impacts on villagers. From a development-as-modernization perspective, we outline three main processes of land consolidation: village mergers and resettlement, land circulation to rural cooperatives, and rural industrial development. Overall, the effects of land consolidation on the livelihood of resettled villagers are positive. This system generally improves housing and living conditions through increased levels of off-farm employment and income, but there are a number of barriers that may hinder a villager's ability to find different employment. Housing and neighborhood characteristics have significant effects on the life satisfaction of villagers.
\end{abstract}

Keywords: rural restructuring; land consolidation; resettlement; life satisfaction; China

\section{Introduction}

Rural livelihood and land-use are undergoing an unprecedented transformation in China due to many interrelated processes. The key drivers of change include urbanization and industrialization which has led to the loss of rural habitats and cropland [1-6]; the migrant worker phenomenon where more than 200 million rural dwellers have migrated to cities to earn a living and its associated land-use impacts such as cropland abandonment and rural hollowing [7,8]; large-scale development projects such as the Three Gorges Dam and the South-North Water Transfer Project that convert farmland and rural homes into reservoirs, quarries, pipelines, etc. [9-11]; environmental/conservation resettlement typically in the ethnic minority regions such as Tibet and Inner Mongolia [12-14]; poverty alleviation resettlement that involves the voluntary resettlement of impoverished farmers to urban centers $[15,16]$; and the Grain-for-Green program that supports and incentivizes farmers to convert sloped cropland 
into forest or grassland for ecological benefits $[17,18]$. These processes of rural restructuring have highly uneven consequences. While rural areas near urban centers have experienced the benefits of development, remote inland areas have fewer opportunities to develop [19]. It is estimated that the average income in cities is threefold of that in rural areas, and the gap between cities and rural areas is still widening in terms of income, education, environmental quality, health-care access, etc. [20-23].

Land consolidation is an important but controversial driver of rural restructuring in China. In China's rural land system, the land is owned by village committees, which are collective economic organizations of farmers. Since the adoption of the household responsibility system in 1981, rural households have been given the right to use the land, which they have been contracted to work. Every rural household manages its own contracted farmland, which becomes the primary source of household income. However, with the rapid process of China's urbanization in the past thirty years, millions of villagers have moved to the cities, which has led to serious problems of cropland abandonment. Moreover, farmland is often divided into many small pieces, which limits mechanized and large-scale agricultural production. In 2006, the government initiated BNRC initiative, a national-level rural development program that aims to improve rural governance in the context of serious challenges such as rural land fragmentation, cropland abandonment, and rural hollowing by concentrating rural settlements [24-26]. The BNRC initiative also aims to narrow the living standard gap between urban and rural areas through the promotion of in-situ urbanization in rural areas, employment transformation, and rural industrial development. Land consolidation emerged as an important tool to achieve the objectives. Typically, a number of villages are consolidated into a centralized community, and the vacated residential land can then be converted to farmland. By concentrating dispersed rural populations, the government can provide public services and infrastructure such as roads, schools, hospitals, electricity, water, and sanitation to rural dwellers more efficiently. At the same time, the reduction of rural construction land use accompanied by the increase in agricultural land allows cities to expand under the "no net loss" land-use policy $[27,28]$. The government, therefore, considers rural restructuring through land consolidation as a win-win strategy that positively influences both food production and the living conditions of rural households [24]. However, the reliance on forced relocation has resulted in the violation of farmers' rights and interests and often leads to resistance and even violent protests [26].

Rural land consolidation and the BNRC initiative are emerging as a new research area in China. However, the processes through which land consolidation occurs and the experience of farmers who are resettled into new rural communities remain understudied topics. Most studies focus on the objectives, conditions, significance, and existing problems of the land consolidation project from macro policy perspectives. However, few studies explore the process and mechanism from micro-case perspectives, and few studies reveal the impacts of the land consolidation project on villagers. Without such knowledge, it is difficult to understand how and to what extent land consolidation promotes rural development and urbanization and, ultimately, the welfare of the rural population. For resettled villagers, not only their lifestyles but also their livelihoods are changed fundamentally during and after land consolidation. Therefore, we need a better understanding of the impacts, both positive and negative, on the affected farmers. With a detailed empirical analysis that draws on a case study conducted in Northeast China, this paper reveals key processes and mechanisms of China's land consolidation project and its impact on the resettlers. The paper proceeds in five parts. The second section documents the methods, including the study area, data sources, and resettlement compensation. The key mechanisms of the land consolidation program are then presented in the third section. The fourth section discusses the life changes of villagers after land consolidation, followed by factors that influence villagers' life satisfaction. The paper concludes with some final thoughts on the implications of the findings. 


\section{Materials and Methods}

\subsection{Conceptual Framework}

China's land consolidation project is closely linked to concepts of modernity or modernization. In development theory, the notion of modernization refers to the transformation from traditional societies to modern societies and encompasses processes such as urbanization, industrialization, and the increased use of technology $[29,30]$. We developed a conceptual framework to illustrate that these processes of modernity drive the land consolidation project and how these processes are causally linked to material changes and life satisfaction of the affected villagers (Figure 1). First, the conceptual model identifies three processes of land consolidation, i.e., rural urbanization from village merger and resettlement, the development of rural industries, and farmland circulation. Second, the processes of land consolidation cause material changes that affect various aspects of the rural dwellers' lives, such as housing, living condition, livelihood, and income. Third, these changes have different impacts on life satisfaction.

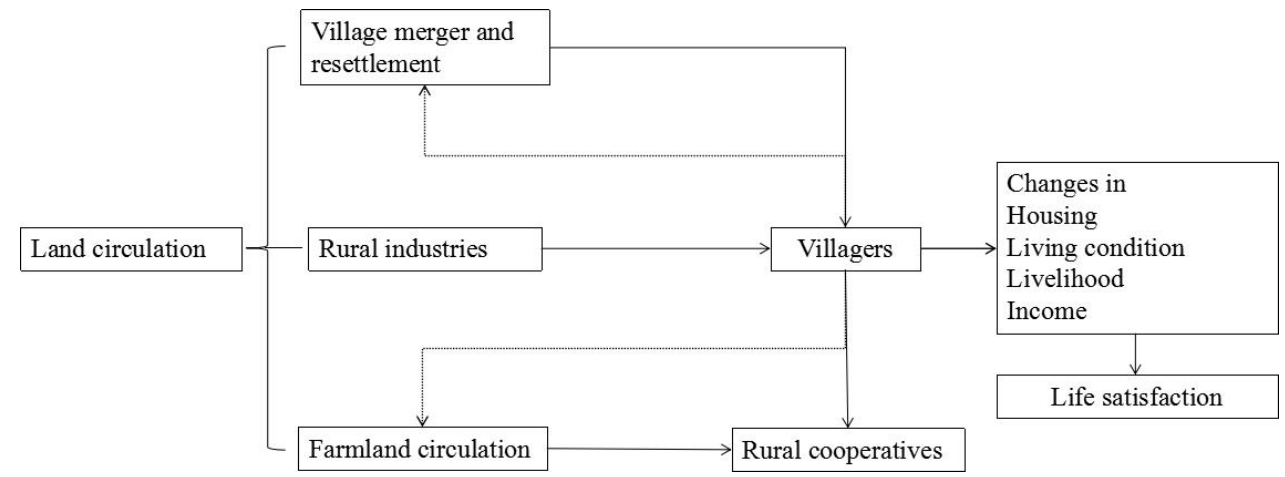

Figure 1. Conceptual model.

\subsection{Study Area}

Chenjiadian, the study area of this project, is located in the town of Helong in Jilin Province, Northeast China. Chenjiadian is an administrative village that consists of ten natural villages, 793 hectares of farmland, and is located about $16 \mathrm{~km}$ from Changchun, the capital of the Jilin province (Figure 2). There is a total of 979 households and 3334 people living in Chenjiadian. Chenjiadian initiated the BNRC program in 2008, and, therefore, sufficient time has passed to establish a suitable case study to examine the impact of land consolidation. A centralized rural community, located at Village 3, was built to house the resettled families.

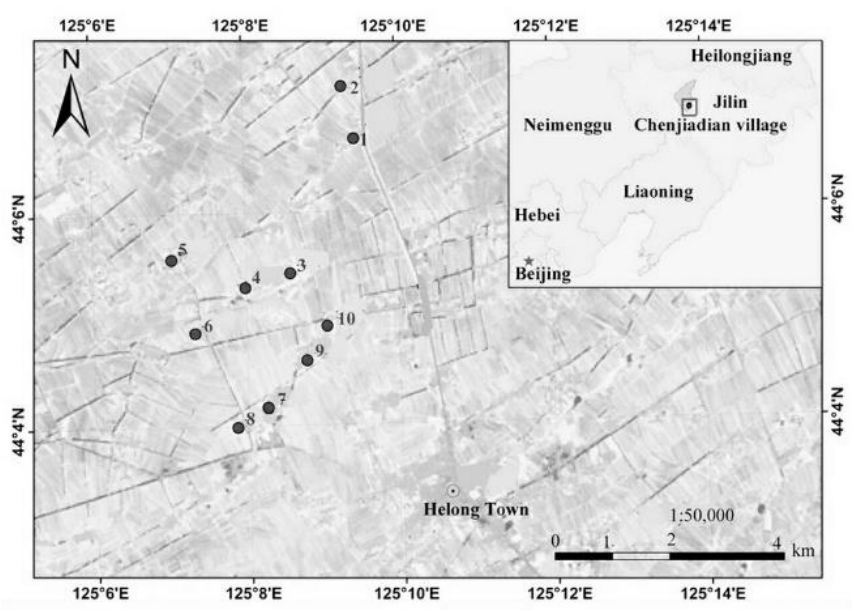

Figure 2. The location of Chenjiadian and the distribution of the ten natural villages. 


\subsection{Data Sources and Methods}

A mixed-method approach was used in this study. Both qualitative and quantitative methods were employed through questionnaires and open interviews. Fieldwork was conducted in June 2014. The land circulation in this area was voluntary. Approximately $60 \%$ of the villagers decided to move to the new neighborhood. If villagers did not agree with the policy and were not willing to move, then they could stay in their original homes. For surveyed respondents, we chose to focus on the villagers who had moved to the new village for our survey. To recruit respondents, we employed a personal approach and visited them at home. If residents were not at home, we skipped that address. The visits took place during the daytime and also in the evening. The survey was conducted independently. There was no government involvement, and the respondents were informed that the interviews were confidential, and their responses would not be passed on to the government. Based on our judgment, the respondents expressed their true thoughts on land consolidation. Part of the questionnaire was filled in by interviewers at the respondents' houses, and another part was completed by the respondents themselves and collected and checked later. A total of 275 questionnaires were collected from local residents, and we also conducted interviews with village officials. The questionnaires consist of four sections: (1) socio-economic and demographic characteristics of the household, (2) resettlement and housing compensation, (3) land circulation and livelihoods, and (4) changes in living conditions (housing, traffic, neighborhood, education, etc.).

In our analysis of material changes caused by land consolidation, we focused on how the experience may vary among different age groups. Existing studies have suggested that age could be an important differentiating factor. For example, Wang et al. (2014), in their empirical study, found that land consolidation was largely opposed by older people because of their stronger attachment to traditional lifestyles [26]. According to our survey, $8 \%$ of the respondents were in the 18-30 age group, $37.45 \%$ in the $30-50$ age group, $22.91 \%$ in the $50-60$ age group, and $31.64 \%$ in the above 60 age group. This age structure is typical of China's rural populations. Lower education levels are also typical of rural populations: $53.45 \%$ of the respondents completed only primary school (six years of education), $38.91 \%$ completed junior secondary (nine years of education), and only $2.55 \%$ have college or university degrees.

A multiple regression analysis was used to identify the predictors of life satisfaction. Because of the relatively small sample, it was necessary to make a pre-selection of potential independent variables. Based on the bivariate relationships between household, housing, and neighborhood characteristics on the one hand and life satisfaction on the other (significant correlations, t-tests, and analyses of variance), we selected the following predictors: household characteristics (age, education, household size, housing space, better job opportunity, and non-land income), housing characteristics (housing condition and housing quality), and neighborhood characteristics (neighborhood environment, traffic, social ties with neighborhoods, education facilities, medical facilities, and entertainment facilities). These variables were included in the regression analysis. Tests on linearity, multicollinearity, and the distribution of residuals show that conditions for this analysis are met.

\section{Results}

This section will describe the key processes of land consolidation, followed by an analysis of material changes associated with land consolidation in terms of housing and living conditions and livelihood. We will then reveal the life adaptation and satisfaction scores for different age groups after land consolidation. Finally, the regression model is adopted to understand the key factors that influence life satisfaction after land consolidation.

\subsection{Key Processes of Land Consolidation}

Our field observations and interviews show that land consolidation consists of three distinct but closely related processes: (1) village mergers and resettlement, (2) land circulation to rural cooperatives, 
and (3) the fostering of new rural industries. The primary stakeholders of land consolidation in Chenjiadian are the village committee, the real estate developers, and the villagers. The village committee (cunmin weiyuanhui) of Chenjiadian is a self-governing organization elected by the villagers and is responsible for various village development functions and played a key role in all of these mechanisms. The village committee acted as the planner, organizer, and promoter in terms of formulating land consolidation plans, inducing investment to the village, and encouraging the villagers to participate in the village merger and land circulation. The real estate developers, based on the housing needs of the villagers, designed and constructed the new rural community. The villagers played little role in decision-making but were the primary beneficiaries of land consolidation through land circulation benefits and improvements in housing and living conditions. Therefore, we could consider land consolidation as a bottom-up approach to governance.

\subsubsection{Village Merger and Resettlement}

Land consolidation in Chenjiadian began with a village merger and resettlement process. A new rural community with a concentrated residential area was built at the location of Village 3 (See Figure 1). The location was chosen because of its proximity to a major thoroughfare, the village committee office, and the availability of flat land for construction. The costs of the construction project were divided between local government support and investment from the real estate developers. Chenjiadian was a pilot project in northeast China; therefore, the provincial government provided 1.14 million RMB (RenMinBi) in funds to support the construction of the new rural community. A further 24 million $\mathrm{RMB}$ was invested by the local government. As a result of this generous funding, the new resettlement community was equipped with high-quality, modern infrastructure (e.g., parkland, sports facilities, central heating, and telecommunication network) and high-rise buildings, which completely changed the traditional rural settlement structure.

Villagers resettled from the ten natural villages, dispersed across different locations, to the new community in 2013. The resettlement has proceeded in stages. In the first stage, five modern residential apartment buildings (mostly six stories high) were built in 2012 and could accommodate 316 households. In the second stage, another ten apartment buildings were built in 2013, and a further eight residential buildings were completed at the end of 2014. The new residential area could accommodate approximately 1530 households. As of the time of this study, around two-thirds of households in Chenjiadian had bought the new housing, one-third of households had resettled into the modern residential buildings, and the remaining one-third of households would be relocated after the furnishing of the new housing is completed.

This project resulted in the creation of new farmland, which was another important funding source-he original housing in the scattered villages collectively occupied about 144 hectares of land. The total construction land of the new rural community, which has much higher population density as people move from houses to apartments, is only 20 hectares, which means that the village merger created 124 hectares of net new farmland. This plays an important role in financing the land consolidation initiative. In 1999, in order to protect arable farmland from urbanization and other threats, the central government established the "no net loss" policy, which stipulated that any increase in urban construction land must be offset by the reduction of rural construction land (hence the creation of new farmland) of equal size [31]. In this new policy environment, village mergers have become an important mechanism to sustain the growth of cities. Through village mergers and resettlement of people into new villages, rural land that had previously been used for dwellings can be converted to farmland. This allows the local government to appropriate rural land in the outskirts of cities and sell it to developers, which generates financial support for the land consolidation initiative. Based on the "no net loss" policy, Chenjiadian obtained a total of 68 million RMB in funding in 2011 through the consolidation of 14.06 hectares of rural land. The village expected to eventually receive up to 400 million RMB of funding the consolidation of 80 total hectares of farmland. 
The funding received through the "no net loss" policy was principally distributed to the villagers. The village committee formulated the relocation compensation standards and established an assessment organization to evaluate the price of villagers' original housing and courtyard and displayed the results publicly to increase transparency. The relocated villagers of Chenjiadian were compensated in two ways. The first form of compensation was a lump-sum payment for housing demolition. The village committee defined rates for standard compensation according to the type of building owned by the villagers: $2400 \mathrm{RMB} / \mathrm{m}^{2}$ for triangle-roof housing built from cement (daozhifang), $2300 \mathrm{RMB} / \mathrm{m}^{2}$ for flat-roof housing built with cement (qijifang), $2200 \mathrm{RMB} / \mathrm{m}^{2}$ for housing built from mud and tile (niwafang), and $2000 \mathrm{RMB} / \mathrm{m}^{2}$ for housing built from soil (tufang). Second, the yard, wells, fruit trees, and other above-ground structures that were part of or next to the house were compensated on a case-by-case basis according to the actual situation of individual households. The village committee determined the amount of compensation according to the established rules, and the results were made public to all villagers. The process of compensation, therefore, seemed relatively fair and transparent. According to our interview, the village committee set up a special measurement team to measure the housing area of the villagers' homes and publicize the measurement results. On average, each household received 240,300 RMB in housing compensation.

In addition to monetary compensation, the villagers also enjoyed preferential purchase of new apartments in the new village at a subsidized rate. The regulation stipulated that the preferential housing price for affected villagers was $900 \mathrm{RMB} / \mathrm{m}^{2}$ and $1500 \mathrm{RMB} / \mathrm{m}^{2}$ in 2011 and 2013, respectively, which was significantly cheaper than the normal market housing price which was $1400 \mathrm{RMB} / \mathrm{m}^{2}$ and $2100 \mathrm{RMB} / \mathrm{m}^{2}$ in 2011 and 2013, respectively. The apartments were typically similar in size to the demolished homes and, therefore, the farmers could afford a new apartment with the cash compensation of the original house, and still have a sizeable surplus of compensation for other purposes.

\subsubsection{Farmland Circulation to Rural Cooperatives}

Since the adoption of the household responsibility system in 1981, rural households manage their own contracted farmland, which means that the farmland of the whole village is divided into many small lots. One drawback of the system is that the family farming structure and the small size of agricultural plots make it difficult to specialize in certain types of farming as well as carry out large-scale operations. Since the villager merger and resettlement process, the distance between the residence and farm has increased, which means that the farm is no longer convenient for farming and storing harvested grain. In response, to better integrate land resources and improve land-use efficiency, rural cooperatives have been established, and farmers are encouraged to transfer their land to rural cooperatives as shareholders. In this way, the rural cooperatives can manage the farmland and, through its larger scale and a higher rate of mechanization, can generate more profits. At the same time, villagers can have some relief from heavy and time-consuming agricultural work to instead work at companies and factories or to do odd jobs.

Villagers who have circulated their land to a rural cooperative receive an annual payment. The village committee determined the value of these annual payments according to the profit generated by the rural cooperative in that year. The annual payment per hectare increased from 100,000 RMB in 2007 to 120,000 RMB in 2011 and 150,000 RMB in 2013. Until now, a total of 480 hectares of farmland have been circulated to rural cooperatives. According to our survey, $66.30 \%$ of households have transferred all of their farmland, and $4.03 \%$ have transferred a portion of their farmland. According to our survey, on average, each household receives 10,169.2 RMB for their annual payment from the rural cooperative.

\subsubsection{Fostering Rural Industries}

Before land consolidation, industries were quite underdeveloped in Chenjiadian, which had only three small-scale factories that primarily specialized in brickwork. The village merger and land circulation led to a concentration in the workforce of non-agricultural work and, therefore, 
enable the development of rural industries. In order to develop industries in the village, the village committee founded three rural professional cooperatives in vegetable growing, agricultural machinery, and poultry breeding in 2008, and 48, 53, and 56 households were involved as stakeholders in the cooperatives, respectively. In 2009, the village committee founded three joint-stock companies that specialized in landscaping and gardening, the distribution of agricultural products, and agricultural means of production. In total, these village enterprises created about 400 jobs. The employees of the enterprises include both staff from village committees and some land-circulated villagers, which assist in the transition of employment for some villagers.

\subsection{Material Changes in Land Consolidation}

\subsubsection{Housing and Living Conditions}

The housing structure, condition, and quality have changed as a result of the land consolidation process. The housing in many of the original villages was one-story brick or earthen houses (Figure 3). There were few facilities other than basic electricity and water services. During winters, villagers relied on firewood, charcoal, or coal for heating. After resettlement, the villagers moved into modern residential buildings (mostly six stories high, Figure 4). The apartment units came furnished with basic amenities such as toilets, kitchens, and bathrooms. Land consolidation has improved the living environments and housing conditions of the villagers and allows the government to better use its resources to equip the new village with modern infrastructure and service facilities such as telecommunication, water supply, and drainage, heating systems, greening, and waste collection.

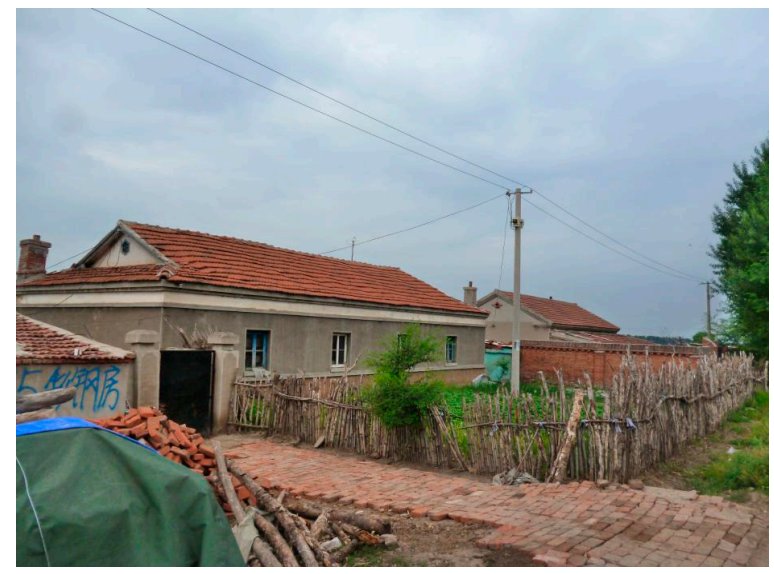

Figure 3. Housing in the original village.

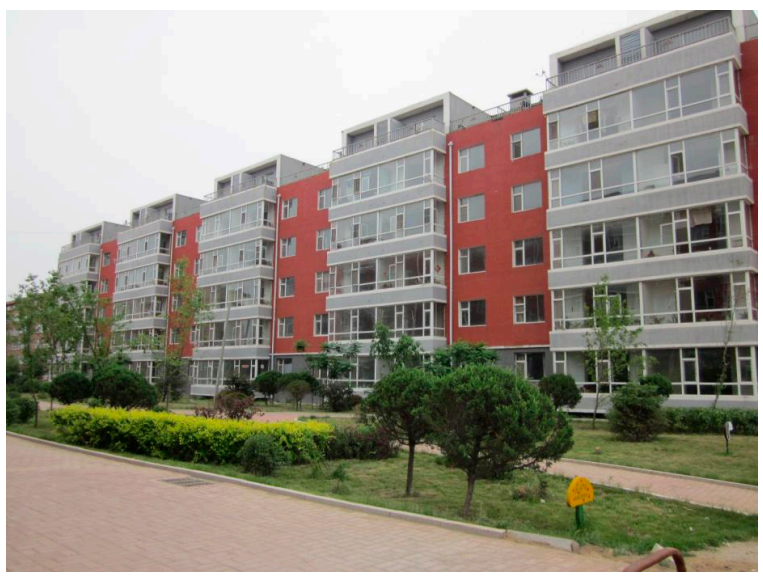

Figure 4. Housing in the resettlement community. 
In the survey, respondents were asked to evaluate changes in their living conditions before and after the land circulation. A score of 5 was given to those who report a significant positive change, a score of 4 to those reporting a somewhat positive change, a score of 3 to those reporting no change, a score of 2 to those reporting a somewhat negative change, and a score of 1 to those reporting a significant negative change. Table 1 presents these results. The difference between different age groups is not significant. Most households reported that housing, environment, transport, and entertainment facilities have been improved as better facilities and property management services have been provided. In terms of relationships with neighbors, respondents generally reported that there is not much change. This is not surprising when we consider that the entire village was resettled to the same place, which preserved the original rural communities and their social connections. The villagers believe that the standard of education, healthcare, and safety has not changed much. According to the respondents, because there is a primary school located in the new residential area, their children can enjoy better primary education. However, there is still no high school in the community, and students must commute daily to the town of Helong. The respondents also indicated that, while the clinics in the new residential area are more convenient, they had limited resources and staff. For serious illnesses, the villagers still had to go to the larger and better-equipped hospitals in a town or city. Regarding safety, although the residential area was built as a gated community to improve security, the walls and gates were not been completed and, therefore, anyone could access the neighborhood, which undermined the security of the community.

Table 1. Perception of change in the living environment.

\begin{tabular}{llllll}
\hline \multicolumn{1}{c}{ Age Group: } & $\mathbf{1 8 - 3 0}$ & $\mathbf{3 0 - 5 0}$ & $\mathbf{5 0 - 6 0}$ & Over $\mathbf{6 0}$ & Total \\
\hline Housing condition & 4.45 & 4.37 & 4.48 & 4.48 & 4.44 \\
Housing quality & 3.95 & 4.07 & 4.08 & 4.20 & 4.10 \\
Environment & 4.23 & 4.23 & 4.32 & 4.41 & 4.31 \\
Transport & 4.05 & 4.37 & 4.49 & 4.44 & 4.39 \\
Neighbor relation & 3.09 & 3.09 & 3.48 & 3.40 & 3.28 \\
Education & 3.45 & 3.48 & 3.36 & 2.99 & 3.30 \\
Healthcare & 3.73 & 3.70 & 3.68 & 3.69 & 3.69 \\
Entertainment & 4.45 & 4.28 & 4.46 & 4.40 & 4.38 \\
Safety & 3.68 & 3.71 & 3.92 & 3.87 & 3.81 \\
\hline
\end{tabular}

(Score 5: a significant positive change; score 4: a somewhat positive change; score 3: no change; score 2: a somewhat negative change; score 1: a significant negative change).

\subsubsection{Livelihood}

Table 2 traces occupational changes among the affected households pre- and post-land consolidation. Before land consolidation, the majority of households either engaged in farming only $(30.18 \%)$ or a combination of farming and odd jobs, such as cleaning and driving taxis (42.18\%). The third most common occupation was doing regular jobs outside the village $(9.46 \%)$. There were very few households that ran small businesses $(6.18 \%)$ or were in regular paid employment in the village (3.28\%). There is a significant age-based difference in the results. Among the older households (>60 years), the majority engaged only in farming. Among the middle-aged households, the most common options were farming and odd jobs (45.10\% for the $31-50$ age group; $58.46 \%$ for the $51-60$ age group). For young households, the most common option was taking up regular jobs outside the village $(36.36 \%)$.

After the implementations of land consolidation, farming was no longer a key source of livelihood. The proportion of households who depended on farming only or farming and odd jobs decreased dramatically to $4.73 \%$ and $13.09 \%$, respectively. This decline was accompanied by a significant increase in households that took odd jobs only $(40.00 \%)$ or were jobless $(17.09 \%)$. Households that ran businesses or were in regular paid employment within the village also increased to $6.91 \%$ and $10.91 \%$, respectively. 
Table 2. Household occupation change.

\begin{tabular}{llllll}
\hline \multicolumn{1}{c}{ Age Group: } & $\mathbf{1 8 - 3 0}$ & $\mathbf{3 1 - 5 0}$ & $\mathbf{5 1 - 6 0}$ & $\mathbf{> 6 0}$ & Total \\
\hline & Before implementing land circulation & & & \\
Only farming & $9.09 \%$ & $18.63 \%$ & $24.62 \%$ & $53.49 \%$ & $30.18 \%$ \\
Farming and odd jobs & $31.82 \%$ & $45.10 \%$ & $58.46 \%$ & $29.07 \%$ & $42.18 \%$ \\
Farming and small businesses & $4.55 \%$ & $2.94 \%$ & $3.08 \%$ & $2.33 \%$ & $2.91 \%$ \\
Farming and regular jobs outside the village & $0.00 \%$ & $4.90 \%$ & $4.62 \%$ & $1.16 \%$ & $3.28 \%$ \\
Only small businesses & $9.09 \%$ & $4.90 \%$ & $1.54 \%$ & $1.16 \%$ & $3.27 \%$ \\
Only regular jobs inside the village & $0.00 \%$ & $1.96 \%$ & $1.54 \%$ & $0.00 \%$ & $1.09 \%$ \\
Only regular jobs outside the village & $36.36 \%$ & $12.75 \%$ & $3.08 \%$ & $3.49 \%$ & $9.46 \%$ \\
Only odd jobs & $9.09 \%$ & $8.82 \%$ & $1.53 \%$ & $3.49 \%$ & $5.45 \%$ \\
Jobless & $0.00 \%$ & $0.00 \%$ & $1.53 \%$ & $5.81 \%$ & $2.18 \%$ \\
\hline \multicolumn{1}{c}{ After implementing land circulation } & & & \\
Only farming & $0.00 \%$ & $4.90 \%$ & $4.62 \%$ & $5.81 \%$ & $4.73 \%$ \\
Farming and odd jobs & $13.64 \%$ & $16.67 \%$ & $12.31 \%$ & $9.30 \%$ & $13.09 \%$ \\
Farming and small businesses & $0.00 \%$ & $0.98 \%$ & $0.00 \%$ & $1.16 \%$ & $0.73 \%$ \\
Farming and regular jobs inside the village & $0.00 \%$ & $1.96 \%$ & $3.08 \%$ & $0.00 \%$ & $1.45 \%$ \\
Farming and regular jobs outside the village & $4.55 \%$ & $0.00 \%$ & $0.00 \%$ & $0.00 \%$ & $0.36 \%$ \\
Only small businesses & $22.73 \%$ & $10.78 \%$ & $1.53 \%$ & $2.33 \%$ & $6.91 \%$ \\
Only regular jobs inside the village & $22.73 \%$ & $15.69 \%$ & $9.23 \%$ & $3.49 \%$ & $10.91 \%$ \\
Only regular jobs outside the village & $13.64 \%$ & $2.94 \%$ & $9.23 \%$ & $1.16 \%$ & $4.73 \%$ \\
Only odd jobs & $18.18 \%$ & $45.10 \%$ & $53.85 \%$ & $29.07 \%$ & $40.00 \%$ \\
Jobless & $4.55 \%$ & $0.98 \%$ & $6.15 \%$ & $47.68 \%$ & $17.09 \%$ \\
\hline
\end{tabular}

The difference across the age groups remains significant. The over-60 households have the highest rate of unemployment $(47.68 \%)$. This is because the land circulation to rural cooperatives allows them to retire from farming but still receive a regular income. Middle-aged households now focus mostly on odd jobs after giving up farming. For the youngest households, there has been a significant shift from regular employment outside the village to regular employment within the village and to operating small businesses, which shows that the younger generations prefer to work close to their home rather than in the city.

Overall, the impact of land circulation on livelihood is significant and is quite different across age groups. For the over-60 age group, land circulation means that they are able to retire and live on income generated from the rural cooperatives. For the 31-50 and 51-60 age groups, land consolidation has encouraged them to take up more odd jobs as land circulation freed them from heavy farming work. For farmers in the 18-30 age group, the impact could be seen mainly in the shift from working in a permanent position outside the village to one closer to home.

\subsubsection{Income}

Table 3 compares household income before and after land consolidation. Before land consolidation, $44.40 \%$ of households had an annual income of over 30,000 RMB, while $22.39 \%$ of households earned between 20,000 and 30,000 RMB annually. Younger households earned significantly more than older households: $77.27 \%$ of the $18-30$ age group earned over 30,000 RMB per year, compared to $59.79 \%$ from the $31-50$ age group, $42.18 \%$ from the $51-60$ group, and $20.00 \%$ from the over-60 group. This is because younger households tended to hold down regular paid jobs, whereas older households mainly relied on low-income farming.

After land consolidation, $21.35 \%$ of the households reported an increase in income, $72.66 \%$ reported no change, and 5.99\% reported a decrease in income. Overall, the proportion of households that earn more than 30,000 RMB increased to 54.85\%, whereas households that earned less than 10,000 RMB decreased to $14.55 \%$. This suggests that land consolidation resulted in a modest improvement in terms of income. The differential earning pattern persisted, with the younger households earning more than older households. In total, $90.90 \%$ of $18-30$ households earn over 30,000 RMB, compared to $73.20 \%$ for 
the $31-50$ age group, $59.37 \%$ for the $51-60$ group, and $21.18 \%$ for the over- 60 group. Land consolidation has the strongest positive impact on middle-aged households. The percentage of households that reported an increase in income in the 18-30 age group, the 31-50 group, the 51-60 group, and the over-60 group was $13.64 \%, 21.65 \%, 29.69 \%$, and $17.64 \%$, respectively.

In 2011, the Chinese government created a guideline that established the poverty standard in rural households as a per capita net income of 2,300 RMB per year. Since a typical household has three to five members, we could define a poverty-level household as a household with an annual income below 10,000 RMB according to these guidelines. Overall, the percentage of poverty-level households in this village decreased from $17.16 \%$ to $14.55 \%$. We saw that these results also followed the differential patterns as income increase, and the percentage of reported poverty-level households in the 18-30 age group, 31-50 group, 51-60 group, and over- 60 group was $0.00,2.06 \%, 4.69 \%$, and $40.00 \%$, respectively.

Table 3. Household income changes.

\begin{tabular}{cccccc}
\hline Age Group: & $\mathbf{1 8 - 3 0}$ & $\mathbf{3 1 - 5 0}$ & $\mathbf{5 1 - 6 0}$ & $\mathbf{> 6 0}$ & Total \\
\hline \multicolumn{7}{c}{ Before land circulation } \\
$<10,000 \mathrm{RMB}$ & $4.55 \%$ & $6.19 \%$ & $9.38 \%$ & $38.82 \%$ & $17.16 \%$ \\
$10,000-20,000 \mathrm{RMB}$ & $0.00 \%$ & $10.31 \%$ & $20.31 \%$ & $23.53 \%$ & $16.05 \%$ \\
$20,000-30,000 \mathrm{RMB}$ & $18.18 \%$ & $23.71 \%$ & $28.13 \%$ & $17.65 \%$ & $22.39 \%$ \\
$>30,000 \mathrm{RMB}$ & $77.27 \%$ & $59.79 \%$ & $42.18 \%$ & $20.00 \%$ & $44.40 \%$ \\
\hline \multicolumn{7}{c}{ After land circulation } \\
$<10,000 \mathrm{RMB}$ & $0.00 \%$ & $2.06 \%$ & $4.69 \%$ & $40.00 \%$ & $14.55 \%$ \\
$10,000-20,000 \mathrm{RMB}$ & $4.55 \%$ & $5.15 \%$ & $12.50 \%$ & $16.47 \%$ & $10.45 \%$ \\
$20,000-30,000 \mathrm{RMB}$ & $4.55 \%$ & $19.59 \%$ & $23.44 \%$ & $22.35 \%$ & $20.15 \%$ \\
$>30,000$ RMB & $90.90 \%$ & $73.20 \%$ & $59.37 \%$ & $21.18 \%$ & $54.85 \%$ \\
\hline \multicolumn{7}{c}{ Change in income } \\
Increase significantly & $0.00 \%$ & $1.03 \%$ & $4.69 \%$ & $5.88 \%$ & $3.00 \%$ \\
Increased & $13.64 \%$ & $20.62 \%$ & $25.00 \%$ & $11.76 \%$ & $18.35 \%$ \\
Unchanged & $86.36 \%$ & $75.26 \%$ & $65.63 \%$ & $70.59 \%$ & $72.66 \%$ \\
Decreased & $0.00 \%$ & $3.09 \%$ & $4.68 \%$ & $9.41 \%$ & $5.24 \%$ \\
Decrease significantly & $0.00 \%$ & $0.00 \%$ & $0.00 \%$ & $2.35 \%$ & $0.75 \%$ \\
\hline
\end{tabular}

\subsection{Adaptation and Satisfaction}

The relocated households overwhelmingly report that they have adapted to living in the new residential area and that they enjoy having similar facilities as urban residents. This reflects how new housing has improved their quality of life and how land consolidation has freed up some of the rural labor force. This is especially true for farmers who have circulated their land to rural cooperatives, whose payments from land rent could sustain their basic livelihood and because farmers have more freedom to choose how much they work and what kind of work they do. The difference in this self-reported rate of adaptation across the age groups is not significant, but we should note that negative views on adaption decrease with age: $9.09 \%$ for the $18-30$ age group, $8.49 \%$ for the $31-50$ group, $4.61 \%$ for the $51-60$ group, and $2.33 \%$ for the over- 60 group (Table 4 ). In other words, younger farmers have found it slightly harder to adapt to their new life. This is likely because younger groups have the highest degree of family responsibilities, such as the education of their children and the health of their elderly parents, and are, therefore, under the greatest pressure to adapt to their new life. In contrast, older generations are usually made up of retirees who face less pressure to adapt.

The majority of respondents across all age groups stated that they were satisfied with their new life, with respondents from the 18-30 and 51-60 age groups reporting higher rates of satisfaction. In terms of changes to living standards, the opinion was mostly positive, with $72 \%$ of respondents indicating their living standard was better or much better after land consolidation and only $3 \%$ indicating it had worsened. 
Table 4. Adaptation to, and satisfaction with the new lifestyle.

\begin{tabular}{llllll}
\hline \multicolumn{1}{c}{ Age Group: } & $\mathbf{1 8 - 3 0}$ & $\mathbf{3 1 - 5 0}$ & $\mathbf{5 1 - 6 0}$ & Over 60 & Total \\
\hline \multicolumn{7}{c}{ Adapted to the new residential area } \\
Very positive & $45.46 \%$ & $18.87 \%$ & $43.08 \%$ & $30.23 \%$ & $30.11 \%$ \\
Positive & $27.27 \%$ & $56.60 \%$ & $44.62 \%$ & $55.81 \%$ & $51.25 \%$ \\
Neutral & $18.18 \%$ & $16.04 \%$ & $7.69 \%$ & $11.63 \%$ & $12.90 \%$ \\
Negative & $9.09 \%$ & $8.49 \%$ & $4.61 \%$ & $2.33 \%$ & $5.74 \%$ \\
Very negative & $0.00 \%$ & $0.00 \%$ & $0.00 \%$ & $0.00 \%$ & $0.00 \%$ \\
\hline \multicolumn{7}{c}{ Very satisfied } & $4.55 \%$ & $6.60 \%$ & $17.19 \%$ & $21.84 \%$ & $13.62 \%$ \\
satisfied & $68.18 \%$ & $72.64 \%$ & $70.31 \%$ & $64.37 \%$ & $69.18 \%$ \\
Neutral & $27.27 \%$ & $19.81 \%$ & $10.94 \%$ & $12.64 \%$ & $16.13 \%$ \\
Dissatisfied & $0.00 \%$ & $0.95 \%$ & $1.56 \%$ & $1.15 \%$ & $1.07 \%$ \\
Very dissatisfied & $0.00 \%$ & $0.00 \%$ & $0.00 \%$ & $0.00 \%$ & $0.00 \%$ \\
\hline
\end{tabular}

\subsection{Regression Analysis on Life Satisfaction}

Two regression models were developed to predict life satisfaction (Table 5). In Model 1, only household characteristics and housing characteristics were included. The results show that the strongest predictors for life satisfaction are age, non-land income, and improvement of housing condition and quality. The results indicate that age is the most significant predictor, with older people feeling more satisfied with life. This is mainly because land consolidation means that they can retire and live on income generated from the rural cooperatives. In addition, non-land income is also a statistically significant predictor. Resettlers with a higher level of non-land income have a higher level of life satisfaction. This suggests that high non-land income provides important material support for people's lives, which can help them to adapt to the neighborhood and feel more secure. The improvement in housing conditions and quality are two highly significant predictors of life satisfaction. The improvement of housing, from one-story brick houses or earthen houses to modern residential buildings furnished with better amenities such as toilets, kitchens, bathrooms and heating facilities, is an important contributor to better life satisfaction.

Table 5. Linear regression model results for the life satisfaction.

\begin{tabular}{lll}
\hline \multicolumn{1}{c}{ Variables } & Model 1 & Model 2 \\
\hline Household characteristics & $\beta$ & $\beta$ \\
Age & $0.132^{* * *}$ & $0.1252^{* * *}$ \\
Education & -0.002 & 0.053 \\
Household size & 0.019 & 0.007 \\
Housing space & 0.000 & 0.000 \\
Better job opportunity & 0.094 & 0.083 \\
Non-land income & $0.06^{*}$ & $0.052^{*}$ \\
Housing characteristics & & \\
Housing condition & $0.198^{* * *}$ & 0.055 \\
Housing quality & $0.149^{* * *}$ & $0.091^{*}$ \\
Neighborhood characteristics & & \\
Neighborhood environment & & $0.123 * *$ \\
Traffic & & $0.139 * * *$ \\
Neighbor ties & & 0.014 \\
Education facilities & & 0.031 \\
Medical facilities & & $0.124^{* *}$ \\
Entertainment facilities & & $0.093^{*}$ \\
Number of observations & 278 & 278 \\
Adjusted R2 & 0.142 & 0.220 \\
\hline
\end{tabular}

${ }^{* * *} p \leq 0.001 ;{ }^{* *} p \leq 0.05 ;{ }^{*} p \leq 0.1$. 
In Model 2, in addition to household and housing characteristics, we also included neighborhood characteristics. The results show that age, non-land income, and improvement in housing quality still have positive effects on life satisfaction. More importantly, improvement in the neighborhood environment, traffic, medical, and entertainment facilities increase the life satisfaction of villagers. The results indicate that neighborhood characteristics can significantly influence life satisfaction, as better-equipped neighborhood facilities enrich the life of villagers.

Overall, increased non-land income and improvement in housing and neighborhood characteristics increased the life satisfaction of villagers in the process of land consolidation.

\section{Discussion}

Viewed from a broader theoretical perspective, the results from this case study illustrate the role of land consolidation as a driver of rural land-use change in China, as well as the importance of understanding the impacts of land consolidation on affected villagers and how these impacts are distributed unevenly across different groups. The findings suggest three areas of research that will need further study to achieve effective land consolidation policy.

First, as a land management policy, land consolidation is not only about spatial resettlement, but more fundamentally, it is about the socio-economic restructuring of rural economy through fostering rural industries and cooperatives. As a complex project, the successful implementation of land consolidation requires the involvement of both top-down and bottom-up governance. In particular, village committees, as the grassroots administrative organizations in rural China, play a key role in land consolidation and the building of rural communities. However, under the Chinese authoritarian governance system, these kind of bottom-up processes are often subjugated to top-down control [32]. Nevertheless, it is important to explore how to better involve local stakeholders in the planning and implementation of land consolidation in order to gain their willingness to participate and respect their requests $[33,34]$.

Second, the multifaceted impact of land consolidation on the resettlers and how this is linked to satisfaction demands more attention [35]. Our results show that land consolidation created significant changes in villagers' livelihood, income, and living environment. After land circulation, farming became increasingly mechanized and the number of farming jobs reduced significantly. Yet, it is challenging for villagers to find permanent, non-farm jobs. Consequently, a change in livelihood does not contribute to better life satisfaction in this study. The people who choose to resettle need stronger support from the government to help them gain new skills and secure better jobs in the city. Another important way to create new jobs in these new villages is to provide more support for the development of new local industries. The non-land income increases the life satisfaction of villagers after the land consolidation process. Land consolidation has also improved both living environments and housing conditions, which also increase villagers' life satisfaction. Resettling villagers from dispersed villages into a centralized community with high-rise housing not only improves housing conditions but also helps to use the land more efficiently. The land from former residential areas is used for farmland reclamation and allows the land to yield its full economic benefits.

Third, we need a better understanding of the uneven impact of land consolidation on various segments of society [36,37]. Our results show that age is an important factor in determining the life satisfaction of resettlers. From a policy standpoint, this further illustrates the importance of facilitating bottom-up participation in order to take full account of different local stakeholders' interests, including those who refuse to participate in land consolidation [38,39].

\section{Conclusions}

This paper has increased our understanding of the process and effects of land consolidation in rural China. From a development-as-modernization perspective, we have shown that land consolidation in rural China aims to achieve the reorganization and optimization of agricultural land-use and living space through village mergers and resettlement, land circulation to rural cooperatives, and the 
fostering of new rural industries. We have also shown that land circulation leads to material changes for villagers. Land circulation improves the living environments and housing conditions of villagers. The impact of land circulation on livelihood is generally positive but is experienced quite unevenly across age ranges. In terms of livelihoods, the key impact is the end of farming as one of the primary livelihoods for individuals, which results in increased levels of off-farm employment and income, but villagers can find it challenging to find permanent off-farm jobs. Based on the results of the life satisfaction questionnaire after land consolidation, we found that improvement in housing quality and better neighborhood environment and facilities increase the life satisfaction of villagers. China is still at an early stage of accelerated urbanization and how the government decides to utilize rural land and labor resources, and how they can find a more balanced approach to development that reduces the disparities between rural and urban inhabitants both have serious implications in sustaining the economic prosperity of the country [40-42].

The results suggest that land consolidation could be an effective way to promote rural development by integrating the resources of the village, land, population, and industry, as well as narrowing the living standard gap between urban and rural areas and promoting in-situ urbanization through employment transformation, increased non-land income, and rural industrial development. When we compare this to previous international and domestic studies where similar large-scale state projects are often discussed in a negative light [43-46], the relatively positive evaluation (as measured by the high satisfaction rate) of this land consolidation project may be due to two reasons. First, whereas forced resettlement is typical inland consolidation, the project under scrutiny in this study is genuinely voluntary, and non-participation was allowed. Second, the project received generous funding support from the government, which played a key role in ensuring that the infrastructure of the new settlement site is of high standard. However, the results are based on a relatively small sample of respondents from specific neighborhoods in Changchun, China. We should, therefore, exercise caution when generalizing the results. Land consolidation is still a relatively new policy in its pilot phase, and national implementation has not begun. Additionally, every pilot may be different in their policy design. More studies are therefore needed to examine these different policy options and their intended and unintended consequences. More policy and academic attention will be needed to examine the multifaceted impacts on resettlers and how such impacts are distributed across groups. For the rural villagers after the resettlement, it would be interesting to explore changes in their activity patterns and subjective quality of life in future studies.

Author Contributions: Conceptualization and investigation, W.T. and P.Z.; Methodology, W.T. and K.L.; Formal analysis, W.T.; Writing-Original draft preparation, W.T. and K.L.; Writing-Review and editing, W.T., P.Z., and K.L.; Supervision, P.Z.; Funding acquisition, W.T. and P.Z. All authors have read and agreed to the published version of the manuscript.

Funding: This research was funded by the National Natural Science Foundation of China, grant number 41901202, 41571152, 41771179, 41601124; The Educational Planning Projects of Zhejiang Province, grant number 2020SCG227; 135 Planning and Featured Services Projects of IGA, Chinese Academy of Sciences, grant number Y6H2091001, IGA-135-04; The Key Deployment Projects of the Chinese Academy of Sciences, grant number ZDBS-SSW-SQC; National Social Major Science Foundation of China, grant number 18ZDA045 and China Scholarship Council, grant number 201404910592.

Acknowledgments: We are grateful to Chenchen Tian, Ran Gao, and the students from Northeast Institution of Geography and Agroecology. They provided us with generous help in data collection. We are grateful to four anonymous reviewers' comments and suggestions.

Conflicts of Interest: The authors declare no conflict of interest.

\section{References}

1. Deng, X.; Huang, J.; Rozelle, S.; Zhang, J.; Li, Z. Impact of urbanization on cultivated land changes in China. Land Use Policy 2015, 45, 1-7. [CrossRef]

2. Kan, K. The transformation of the village collective in urbanising China: A historical institutional analysis. J. Rural Stud. 2016, 47, 588-600. [CrossRef] 
3. Lin, G.C.S.; Zhang, A.Y. Emerging spaces of neoliberal urbanism in China: Land commodification, municipal finance and local economic growth in prefecture-level cities. Urban Stud. 2014, 52, 2774-2798. [CrossRef]

4. Ong, L.H. State-led urbanization in China: Skyscrapers, land revenue and "concentrated villages". China Q. 2014, 217, 162-179. [CrossRef]

5. Smith, N.R. Beyond top-down/bottom-up: Village transformation on China's urban edge. Cities 2014, 41, 209-220. [CrossRef]

6. Xu, J.; Yeh, A.; Wu, F. Land commodification: New land development and politics in China since the late 1990s. Int. J. Urban Reg. Res. 2009, 33, 890-913. [CrossRef]

7. Chen, R.; Ye, C.; Cai, Y.; Xing, X.; Chen, Q. The impact of rural out-migration on land use transition in China: Past, present and trend. Land Use Policy 2014, 40, 101-110. [CrossRef]

8. Zhang, Y.; Li, X.; Song, W.; Zhai, L. Land abandonment under rural restructuring in China explained from a cost-benefit perspective. J. Rural Stud. 2016, 47, 524-532. [CrossRef]

9. Duan, Y.; Wilmsen, B. Addressing the resettlement challenges at the Three Gorges Project. Int. J. Environ. Stud. 2012, 69, 461-474. [CrossRef]

10. Pohlner, H. Institutional change and the political economy of water megaprojects: China's south-north water transfer. Glob. Environ. Chang. 2016, 38, 205-216. [CrossRef]

11. Rogers, S.; Barnett, J.; Webber, M.; Finlayson, B.; Wang, M. Governmentality and the conduct of water: China's South-North Water Transfer Project. Trans. Inst. Br. Geogr. 2016, 41, 429-441. [CrossRef]

12. Bauer, K. New homes, new lives-the social and economic effects of resettlement on Tibetan nomads (Yushu prefecture, Qinghai province, PRC). Nomadic Peoples 2015, 19, 209-220. [CrossRef]

13. Fan, M.; Li, Y.; Li, W. Solving one problem by creating a bigger one: The consequences of ecological resettlement for grassland restoration and poverty alleviation in Northwestern China. Land Use Policy 2015, 42, 124-130. [CrossRef]

14. Rogers, S.; Wang, M. Environmental resettlement and social dis/re-articulation in Inner Mongolia, China. Popul. Environ. 2006, 28, 41-68. [CrossRef]

15. Lo, K.; Xue, L.; Wang, M. Spatial restructuring through poverty alleviation resettlement in rural China. J. Rural Stud. 2016, 47, 496-505. [CrossRef]

16. Xue, L.; Wang, M.Y.; Xue, T. 'Voluntary' poverty alleviation resettlement in China. Dev. Chang. 2013, 44, 1159-1180. [CrossRef]

17. Komarek, A.M.; Shi, X.; Heerink, N. Household-level effects of China's Sloping Land Conversion Program under price and policy shifts. Land Use Policy 2014, 40, 36-44. [CrossRef]

18. Yin, R.; Liu, C.; Zhao, M.; Yao, S.; Liu, H. The implementation and impacts of China's largest payment for ecosystem services program as revealed by longitudinal household data. Land Use Policy 2014, 40, 45-55. [CrossRef]

19. Liu, S.; Zhang, P.; Lo, K. Urbanization in remote areas: A case study of the Heilongjiang Reclamation Area, Northeast China. Habitat Int. 2014, 42, 103-110. [CrossRef]

20. Gong, P.; Liang, S.; Carlton, E.J.; Jiang, Q.; Wu, J.; Wang, L.; Remais, J.V. Urbanisation and health in China. Lancet 2012, 379, 843-852. [CrossRef]

21. Li, Y.; Long, H.; Liu, Y. Spatio-temporal pattern of China's rural development: A rurality index perspective. J. Rural Stud. 2015, 38, 12-26. [CrossRef]

22. Treiman, D.J. The "difference between heaven and earth": Urban-rural disparities in well-being in China. Res. Soc. Stratif. Mobil. 2012, 30, 33-47. [CrossRef]

23. Xie, Y.; Zhou, X. Income inequality in today's China. Proc. Natl. Acad. Sci. USA 2014, 111, 6928-6933. [CrossRef] [PubMed]

24. Li, Y.; Liu, Y.; Long, H.; Cui, W. Community-based rural residential land consolidation and allocation can help to revitalize hollowed villages in traditional agricultural areas of China: Evidence from Dancheng County, Henan Province. Land Use Policy 2014, 39, 188-198. [CrossRef]

25. Long, H. Land consolidation: An indispensable way of spatial restructuring in rural China. J. Geogr. Sci. 2014, 24, 211-225. [CrossRef]

26. Wang, Q.; Zhang, M.; Cheong, K.-C. Stakeholder perspectives of China's land consolidation program: A case study of Dongnan Village, Shandong Province. Habitat Int. 2014, 43, 172-180. [CrossRef]

27. Lichtenberg, E.; Ding, C. Assessing farmland protection policy in China. Land Use Policy 2008, 25, 59-68. [CrossRef] 
28. Long, H.; Li, Y.; Liu, Y.; Woods, M.; Zou, J. Accelerated restructuring in rural China fueled by 'increasing vs. decreasing balance'land-use policy for dealing with hollowed villages. Land Use Policy 2012, 29, 11-22. [CrossRef]

29. Willis, K. Theories and Practices of Development; Routledge: New York, NY, USA, 2011.

30. Power, M. Modernization Theories of Development. Int. Encycl. Anthropol. 2018, 1-8. [CrossRef]

31. Liu, Y.; Fang, F.; Li, Y. Key issues of land use in China and implications for policy making. Land Use Policy 2014, 40, 6-12. [CrossRef]

32. Lo, K. How authoritarian is the environmental governance of China? Environ. Sci. Policy 2015, 54, 152-159. [CrossRef]

33. Li, Y.; Wu, W.; Liu, Y. Land consolidation for rural sustainability in China: Practical reflections and policy implications. Land Use Policy 2018, 74, 137-141. [CrossRef]

34. Lo, K.; Wang, M. How voluntary is poverty alleviation resettlement in China? Habitat Int. 2018, 73, $34-42$. [CrossRef]

35. Tong, W.; Zhu, L.; Lo, K. Livelihood adaptation and life satisfaction among land-lost farmers: Critiquing China's urbanisation-driven land appropriation. Bulletin of Geography. Socio-Econ. Ser. 2019, 46, 149-161. [CrossRef]

36. Tong, W.; Zhang, P.; Lo, K.; Chen, T.; Gao, R. Age-differentiated impact of land appropriation and resettlement on landless farmers: A case study of Xinghua village, China. Geogr. Res. 2017, 55, 293-304. [CrossRef]

37. Luo, W.; Timothy, D.J. An assessment of farmers' satisfaction with land consolidation performance in China. Land Use Policy 2017, 61, 501-510. [CrossRef]

38. Zhou, Y.; Guo, L.; Liu, Y. Land consolidation boosting poverty alleviation in China: Theory and practice. Land Use Policy 2019, 82, 339-348. [CrossRef]

39. Rogers, S.; Li, J.; Lo, K.; Guo, H.; Li, C. Moving millions to eliminate poverty: China's rapidly evolving practice of poverty resettlement. Dev. Policy Rev. 2019. [CrossRef]

40. Liu, Y.; Long, H.; Chen, Y.; Wang, J.; Li, Y.; Li, Y.; Yang, Y.; Zhou, Y. Progress of research on urban-rural transformation and rural development in China in the past decade and future prospects. J. Geogr. Sci. 2016, 26, 1117-1132. [CrossRef]

41. Long, H.; Zhang, Y.; Tu, S. Rural vitalization in China: A perspective of land consolidation. J. Geogr. Sci. 2019, 29, 517-530. [CrossRef]

42. Li, J.; Guo, M.; Lo, K. Estimating Housing Vacancy Rates in Rural China Using Power Consumption Data. Sustainability 2019, 11, 5722. [CrossRef]

43. Scott, J.C. Seeing Like a State: How Certain Schemes to Improve the Human Condition Have Failed; Yale University Press: Yale, CT, USA, 1998.

44. Wang, M.; Lo, K. Displacement and resettlement with Chinese Characteristics: An editorial introduction. Geogr. Res. Forum 2015, 35, 1-9.

45. Baird, I.G.; Shoemaker, B. Unsettling experiences: Internal resettlement and international aid agencies in Laos. Dev. Chang. 2007, 38, 865-888. [CrossRef]

46. Bang, H.N.; Few, R. Social risks and challenges in post-disaster resettlement: The case of Lake Nyos, Cameroon. J. Risk Res. 2012, 15, 1141-1157. [CrossRef]

(C) 2020 by the authors. Licensee MDPI, Basel, Switzerland. This article is an open access article distributed under the terms and conditions of the Creative Commons Attribution (CC BY) license (http://creativecommons.org/licenses/by/4.0/). 